\title{
The Historical-Religious Context of the Formation of the Holy Apostle Paul
}

\section{Vasile Doru FER*}

\begin{abstract}
From a general perspective, we attempt to analyze and describe, in the first part of our study, the historicalreligious context of the formation of the Apostle Paul, his emergence on the firmament of biblical history as well as the metanoic process that will take place, beginning with his itinerary on the road of Damascus. This moment will become a crucial one in his life, and we say it because from this moment he has the revelation which will persuade him that he had to preach the teachings of Jesus, the crucified, risen and exalted ${ }^{l}$, whom he had recently persecuted. He will preach that even with the risk of suffering for Him and on His behalf. In the second part, we will focus on the propagation of Christianity and on the relations between Christians and the ruling authorities, previous to the missionary activity of Paul, the Holy Apostle.
\end{abstract}

Keywords: Christianity, Judaism, propagation, Synedrion, context, missionary, Saint Luke.

\section{Preliminary considerations}

The Apostle Paul's emergence on the stage of history takes place in a rather tumultuous moment, more precisely in the

* PhD, Lecturer, Faculty of Orthodox Teology „Ep. Dr. Vasile Coman” at University from Oradea. 
middle of a aversion scene. Young and enthusiastic, with the feeling that he serves a noble cause, Saul witnesses the death of Deacon Stephen (Acts 7, 58). Actually, the Apostle Paul's biography begins with the martyrdom of St. Stephen and ends with his own martyrdom.

Very soon, after this terrible picture, we will find him invested with the power of the high public administration, deserting the Church and fighting against those who proclaimed Christ. Having this authority, he used to enter the homes of the people and imprisoned the suspect ones, forcing them to reject their faith before the courts, otherwise being sent to torture (Acts 8, 3-4) ${ }^{2}$.

This will not last too long, because the divine intervention will turn him profoundly from a persecutor of Christians to a preacher of the Gospel of Christ. This metanoic process will begin with his itinerary on the road of Damascus, where during the day, an unusual light is shown to him. In this light, he distinguishes someone addressing him by saying, "Saul, Saul, why do you persecute Me? (Acts 9, 4)". Immediately after the conversation that had followed, Saul became blind for three days, entered the city, and after the intervention of Ananias, to whom the Lord had revealed that Saul would be His chosen vessel, he was baptized (Acts 9: 10-18).

This moment is a crucial one in his life, and we say it because from this moment he has the revelation which will persuade him that he had to preach the teachings of Jesus, the crucified, risen and exalted ${ }^{3}$, whom he had recently persecuted. He will preach that even with the risk of suffering for Him and on

${ }^{2}$ Leon ARION, Compendiu neotestamentar de introducere și exegeză - Ediția a treia, Ploiești, 2010, p. 36.

${ }^{3}$ Eckhard J. SCHNABEL, Early Christian Mission. Paul \& the Early Church, volume two, Illinois, Inter-Varsity Press, Downers Grove, 2004, p. 1031. 
His behalf ${ }^{4}$. After several misinterpretations and divergences with the apostles of Jerusalem, who still saw Saul's potential danger, he was given a rather humble task, namely to preach to the Gentiles the teachings of Christ. This is the moment which confirms his own mission and his task will be to bring light to those who were seated in the shadow of death.

Another earth missionary, arriving in the realm of the unknown, will never live the enthusiasm felt by the Apostle Paul when he first got in the ship that would take him to the islands that were rising in their depths, anticipating and preaching salvation. In his quality of missionary, Saint Paul developed a complex theology and the paganness that was covered by the darkness stirred up at the message that this minister of Christ's teachings brought 5 .

Without much opportunity, the Apostle Paul managed to transform the pagan world into a human community of the righteous. The missionary journeys of Saint Paul the Apostle were a particularly important element that will change the future of mankind. Christ's teachings should not remain in isolation, but only through profound missionary commitment it could be shared by as many nations ${ }^{6}$. He thus became the trumpet of hopes, for the hopeless ones, demonstrating that he was a true soldier of

${ }^{4}$ Conversion is a psychological process through which, after passing, the human soul completely transforms itself into a new self. It is a general regeneration, a rebirth of all our spiritual powers. It is a change in the foundations of our entire edifice. It is exclusive because, as the effect of grace, the crown of which is holiness, must form the opposite of sin and vice. Nicolae M. IONIȚA Ă, Convertirea Sfântului Apostol Pavel - Apologie Biblică, Chișinău, Tipografia Eparhială Cartea Românească, 1932, p. 7.

${ }^{5}$ N.T. WRIGHT, Paul in Fresh Perspective, Fortress Press Minneapolis, 2005, p. 154.

${ }^{6}$ John CORRIE, Dictionary of Mission Theology-Evangelical Foundations, Illinois, Inter-Varsity Press, Nottingham, England, Inter-Varsity Press, Downers Grove, USA, 2007, p. 51. 
Christ who knew how to bring together those who were suffering and to strengthen the hearts of all hopeless people.

\section{Propagation of Christianity and the relationships with the governing authorities previous to Saint Paul's activity}

Before converting to Christianity, the environment in which Saul lived was Judaism. The scene of his first years was Tarsus, a university city dominated by an intellectual atmosphere. He was educated at the Pharisees' school and was sent to religious studies at Jerusalem at the scribe Gamaliel ${ }^{7}$. The political environment in which he later lived and carried out his mission was the Roman Empire, which determines us to affirm that Saul grew up in a cosmopolitan urban culture. ${ }^{8}$ However, this subject can be approached and deepened in two moments about the relationship of the Christian movement with the Jewish and Roman public and civil society.

Saint Luke presents Christianity in the context of his world and time, and Christians, as good citizens who do not violate Roman laws, and as argumentation of the affirmations, St. Luke states at the end of the Book of Acts that Saint Apostle Paul preaches and teaches in Rome "with all boldness, without any hindrance" (Acts 28:31).

The government authorities most frequently encountered in this context and to which we refer are the Jewish and the Roman ones, authorities that St. Luke treats quite differently. For a correct assessment of this theme, there should be abandoned the tendency to project over this lukan period, this tense report between Christianity and political power, tensions that have

7 Ioan BRIA, Dicţionar de Teologie Ortodoxă A-Z, București, Editura Institutului Biblic și de Misiune al Bisericii Ortodoxe Române, 1994, p. 294.

${ }^{8}$ Radu CIOBANU, Mic Dicţionar de Cultură Religioasă, Editura Emia, 2003, pp. 54-55. 
generated the later persecutions. In the first thirty years of Christian history there are no conflicting reports of Christianity with the Roman empire and the political authorities.

Generally, the Jewish officials are presented in an unfavorable light, although St. Luke makes a clear distinction between the bishops belonging to the Sadducees' party and the Pharisees. The Pharisee Gamaliel is portrayed as one who defends the apostles, even when the Apostle Paul found his defenders among the Pharisees (Acts 23, 6-10). In this way there is revealed the literal intelligence of St. Luke that offers a rather diverse framework about how the Herodians princes treated both Jesus and Christians.

Herod Antipas ${ }^{9}$ listens to Jesus with interest and finds Him innocent, but when He refuses to answer some questions, he and his soldiers treat Him with contempt and mock at him (Luke 23: 8-11). The same author in the book of Acts of the Holy Apostles describes Herod Agrippa in a false image because he orders that Jacobs, the brother of John should to be killed, and, to please the Jews, he arrests the Apostle Peter (Acts 12, 2-3) ${ }^{10}$. Instead, the

${ }^{9}$ Herod Antipa - the tetrarch reigned between 4-39 AD, he was the master of Peree and Galilee. He was remarked both on the religious and political areas. As political references we say that Herod Antipa moved the capital of Galilee from Sephoris to Tiberia. In the religious field, Herod Antipa was particularly noted by commanding the arrest of St. John the Baptist, and later accepting his beheading (Luke 3: 19-20). ( Marius ȚEPELEA, Repere istorice privind Biserica primară, Oradea, Editura Universității din Oradea, 2011, p. 59).

${ }^{10}$ Herod Agrippa I (37- 44) was born in the 10th century BC, being the son of Aristobulus and Berenice and grandson of Herod the Great. Raised at the Imperial Court in Rome, he was thrown into prison by Emperor Tiberius, and was subsequently released by his friend Caligula. He becomes emperor, reuniting under his scepter all the states that were under his grandfather Herod the Great. He is mentioned in the book of Acts of the Holy Apostles (chapter 12, 1, 6, 11, 19 and 21) as a murderer of St. John 
activity and image of Agrippa II is presented positively (Acts 25, 13-26, 32). He wishes to obey the Apostle Paul, and when he speaks, he comes in his defense and he claims his innocence even twice.

In short, we might say that St. Luke judges the Herodian princes according to their attitude both to Christ the Savior and to the Holy Apostles, and later to Christians as well.

However, as Christianity is not a private experience, it is obvious that he also approached the relations with the public authority. To this there is added the fact that the Roman authority occupying Palestine at that time treated Jesus Christ as a rebellious one, and he practically refused to be involved in the discovery of the truth.

This has heavily touched upon Christianity, at least in the first century, casting a shadow of suspicion on its political loyalty. To some extent, Christians had to demonstrate their own political innocence.

At first, Christian converts in Palestine, and particularly those in the capital Jerusalem, struck the Jewish authority represented by the Synedrion. This supreme council was not a cultural or religious academy, but a court for religious and civilian issues related to the religious world of both the Palestinian Jews and the Diaspora ${ }^{11}$.

the Apostle, and then puts the Holy Apostle Peter in chains. He died when he was coming to the throne in order to speak, being struck by the angel of the Lord for not giving glory to God (Acts 12: 21-23). Ioan MIRCEA, Dicționar al Noului Testament, București, Editura Institutului Biblic și de Misiune al Bisericii Ortodoxe Române, 1995, p. 234.

${ }^{11}$ In the period after the exile a supreme political ecclesiastical court, called the Great Synedrion or the Sanhedrin, was established in Judea (Numbers 11: 16-17). It consisted of the aristocrats of the Jewish society. During the Roman Procurators, the Sanhedrin will broaden its sphere of action and increase its powers, and in the time of the Savior, the the Synedrion will appear as the highest court of justice of the nation and the strongest 
In the presence of the Jewish authorities, St. Luke admits the civil disobedience of the Holy Apostles. St. Peter and John go to the temple, where they cure a lame, and the world is impressed. Then, St. Peter explains that Jesus, the One killed by the rulers of the people, but whom God raised, had done the healing of this man ${ }^{12}$. As they were speaking in front of the the crowd, the chief of the temple and the Sadducees came to the priests, troubled that they were teaching the people, and were proclaiming Jesus' resurrection from the dead. And putting their hand on them, they put them under guard until the next day, for it was evening (Acts 4, 1-3). Not the people, but the officials of the temple are those who contest the Christian movement. The murder of Jesus was not decided by the people, but by the ruling class in Jerusalem subordinated to the Roman power.

The political process of Jesus constitutes the first important contact with the Roman power. On that occasion, Pilate did not act as a courageous magistrate who defended the oppressed, although he had tried to deliver Jesus (Luke 23:16, 20, 2; Acts 3,

authority of the country. From the writings of the New Testament and from the information of Joseph Flavius, we find out that three categories of people belonged to the Synedrion: the archbishops, the scribes and the elders. The Sanhedrin exercises its authority over all the Jewish communities in the world. This explains why Saul demands the approval of the Synedrion to arrest and bring the Christians of Damascus to Jerusalem. So, in the competence of the Synedrion there entered all the spiritual and religious issues and, in general, all those problems that were related to Judaism and which the Roman authority was not interested in. (Dumitru ABRUDAN, Emilian CORNIȚESCU, Arheologia Biblică, București, Editura Institutului Biblic şi de Misiune al Bisericii Ortodoxe Române, 1995, pp. 169-171).

12 Mikeal C. PARSONS, Luke-Storyteller, Interpreter, Evangelist, Massachuetts, Hendrickson Publishers, Peabody, 2007, p. 3. 
13) but preferred to witness the dialogue between the synedrium and the crowd with a certain non-persistence ${ }^{13}$.

Seeing that, the bishops and scholars force his hand, according to St. Luke, the blame of Jesus' death (Luke 24:20), for the most part, having be imputed to them. On many occasions, in describing the story of the Passion, (Luke 22: 52, 23, 4-5, 10, 13 16), St. Luke presents the bishops and the Jewish authorities as enemies of Jesus, but making the distinction between them and the people. Discredited and disregarded, the Savior Christ remains alone. Loneliness in the presence of death can lead to despair, and the words spoken by Christ the Savior: "My God, my God, why have you forsaken me!" shows the Lord "fighting for the last time as a man, with the temptation of despair, in the presence of death"14.

Not only in the process of the Savior, but also in other situations, Saint Luke reports the sarcasm and malignancy of the ruling class of the chosen people. They enjoyed many privileges, which sometimes abused and used them for personal reasons. For example, the officials of the temple described in the book of Acts 4, 1-3 had at their disposal a police force commanded by a captain of the temple. The Sadducees whose name comes from

${ }^{13}$ Pontius Pilate was the fifth of the Roman Prosecutors of Judea and Samaria, and was appointed to this position by Caesar Tiberius in the twelfth year of his reign, more precisely the year $26 \mathrm{AD}$, position that he fulfilled until the year 36 AD. Good Administrator, Pilate had a contempt for the Palestinian Jews, which he did not conceal and did not seek to attenuate. He was arrogant and unstable, and for his bizarre character we have the testimony of his contemporary, King Herod Agrippa I, who, in a letter addressed to Emperor Caius Caligula, judges him harshly, classifying him as inflexible, brutal and arrogant. Grigorie MARCU, ,Trei portrete neotestamentare: Iuda Iscarioteanul, Pilat din Pont și Claudia Procula" în rev. Mitropolia Ardealului, nr. 3-4, 1958, pp. 195-196.

${ }^{14}$ Nicolae I. NICOLAESCU, „Patimile Mântuitorului după Sfintele Evanghelii”, în rev. Studii Teologice, nr. 1-2, 1953, p. 111. 
the archbishop Zadok movement to which the great aristocratic families in Jerusalem joined, secular and priestly, having a major influence on the temple. Under the rule of Alexander Ianeus, the Sadducees gained a great political power, but he, on the deathbed, advised his wife Alexandra to summon the Pharisees to the government, firmly convinced that they would show him obedience ${ }^{15}$.

If someone had the courage to speak something contrary to their teachings, they were willing to do anything to condemn him. When the disciples of Jesus taught the people, preaching Jesus and His Resurrection from the dead, they were irritated, because the Sadducees did not really believe in the resurrection, because it was a dogma foreign to the old written bible tradition: "And the second day, their chiefs and the elders and scribes in Jerusalem, and Ana the high priest and Caiaphas and John and Alexander and those of the aristocratic nation, gathered together" (Acts.4: 5-6).

Before this cleric and secular aristocracy in Jerusalem, the two apostles were taken and interrogated, and then intimidated, commanding them not to preach in His name. Saint Peter then responds for the first time, appealing to the principle of the objection of conscience that challenges the unjust order of the Sanhedrin: "Judge whether it is right for God to obey you more than God; for we can not fail to talk about what we have seen and heard "(Acts 4, 19-20). This culture, which arises from experience and freedom of consciousness, is also the criterion of unmasking and demystification of a power that abuses its role. The authority of the Synedrion was in fact a juridical-religious character, insofar as it interpreted the will of God for the observing Jews.

15 Josephus FLAVIUS, Istoria războiului iudeilor împotriva romanilor, Traducere de Gheneli Wolf și Ioan Acsan, București, Editura Hasefer, 2004, p. 24. 
When they were released, Peter and John went to the Christian brothers and the next day they began to talk again about Jesus in the Temple. "And the high priest rose, and all the people of the Sadducees with him were filled with envy. And they took the apostles and cast them into the public dungeon "( Acts 5, 1718). But they are released by the angel of the Lord during the night. This is the first release miraculously mentioned in the book of Acts of the Holy Apostles and the second is that of Peter in the dungeon of Agrippa I.

While the Synedrion was reunited, in the pompa magna, waiting for the appearance of the accused, the guards found the dungeon empty, being told in turn that the two disciples of Jesus taught the people in the temple. Then the captain went with the servants, but brought them not by force, for they feared the people not to stone them (Acts 5:26). The people, therefore, were on the part of Jesus' disciples, as they were on the part of the Savior Jesus Christ during His earthly activity ${ }^{16}$.

Again, in the Synedrion, which reaffirms the already given order, not to speak in the name of Jesus, Peter repeats the principle of the objection of consciousness: "We must obey God more than men" (Acts 5:29).

This famous sentence has a similar parallelism in Socrate's answer given to the Athenian judges, but the disobedience to the legitimate authority that the Synedrion was, is not made in the name of an arbitrary or subjective principle, but based on faithfulness and faithfulness to God: "And the witnesses of these works are we and the Holy Spirit whom God has given to those who obey Him" (Acts 5:32). Their disobedience is motivated by their obedience to God. Obedience and respect are no longer a

16 Constantin PREDA, „Credinţa şi viaţa Bisericii primare. O analiză a Faptelor Apostolilor", în rev. Studii Teologice, seria a II-a, anul LIV, nr 12, 2002, p. 218. 
virtue when they go against the principles of consciousness inherent in the pursuit of the fulfillment of God's will and the true good of man.

Gamaliel, the representative of the Pharisees ${ }^{17}$ (the more liberal Jewish movement), to which the Apostle Paul also belonged, states: There have been other messianic movements that have revolted, but which have been destroyed. If this movement comes from God, it is useless to fight it. If, instead, it is a human movement, it will end up like all the other messianic reforms or innovations. There are two examples: Teuda's and Judas Galileo's. The Synedrion follows his counsel, but in an incoherent way (Acts 5, 40-42). St. Luke is sure that the Apostles behaved in the most coherent way (Acts 5, 38-39), even though there is no doubt that they committed a civil disobedience to the authority in Jerusalem.

This was, therefore, the position of the first Christians towards the Jewish political power. Beyond the historical and contingent motivations, there are also the ideal motivations of their choice: in the name of Jesus Christ the Christian movement claims its own freedom by following Him and His Teachings.

\section{Conclusions}

A second confrontation with the Jewish authority is reported in chapter 12 of The Acts of the Holy Apostles. It is a

${ }^{17}$ The name of this religious group derives from the Hebrew פִּ - peruşim,

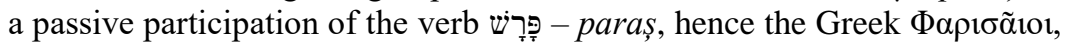
and it is translated as separated or elected. During Alexandru Ianeu they succeeded to gain a very important position in Synedrion. At the beginning of the Christian era, the Pharisees would prove to be law and tradition defenders and their attire and words were full of authority. (Dumitru ABRUDAN, Emilian CORNIȚESCU Arheologia Biblică - Ediția a doua,...p. 331; Viorel Cristian POPA, Noțiuni de Arheologie Biblică- curs anul I, Oradea, Editura Universităţii din Oradea, 2011, p. 108. 
short bracket after a period of relative calm following the killing of St. Stephen, during which the group of Christians in Greece was banished from Jerusalem. However, the group of apostles and Judeo-Christians still maintained reports of peaceful coexistence with Judaism, Christian education based on the love of the neighbour, self-denial, and respect for human value had made those relations to have continuity. ${ }^{18}$

This state of facts lasted until the end of the first Jewish rebellion that would destroy the Temple in the year 70. It followed a more complicated period, marked by the persecutions of Herod Agrippa (37-44), also named in the book of the Acts of the Holy Apostles "King Herod", one of Herod the Great's grandchildren, who became the only king of Judea in the year 44, with the aid and through the Roman media, and through the willingness of Emperor Claudius who succeeds in power and rule between the years 41-44, a large part of the territory that had shaped his grandfather's kingdom ${ }^{19}$ : "And at that time King Herod stretched out his hand to harm some of the Church" (Acts 12,1).

What interests us to highlight in this episode, are the reasons that prompted this violent reaction. Herod Agripa, open to foreign policy but repressive in the internal one, in order to attract the sympathy and support of the conservative group behind the Temple, followed a line of political repression against Christianity which he considered a reforming movement: "And killed with the sword Jacob, the brother of John. And when he saw that he pleased the Jews, he also commanded the capture of Peter" (Acts 12: 2-3).

${ }^{18}$ Grigorie MARCU, „Episoade din viaţa Bisericii creştine a veacului apostolic în expunere şi interpretare lucanică", în rev. Mitropolia Ardealului , anul V, nr 7-8, 1960, p. 531.

19 Nicolae CHIFĂR, Istoria creștinismului I, Sibiu, Editura Universităţii Lucian Blaga, 2007, pp. 24-25. 
While he was imprisoned, awaiting the condemnation, the Apostle Peter is marvelously released by an angel of the Lord and goes to meet the Christian brothers who were all together in Mary's house, John Mark's mother, where the Christian community was assembled to pray for him even at night (Acts 12: 12-17) ${ }^{20}$.

The apostle Peter reappears at the Apostolic Synod of Jerusalem, where he intervenes in favor of Christian freedom against the mosaic law (Acts 15, 7). So, the repression of Herod Agripa remains an isolated episode that did not fundamentally change the propagation of Christianity and the relations between Judaism and Christianity at political level. Judaism as power or authority does not prevent the Christian movement from spreading and developing.

Confrontation with the Roman political power is more delicate and complex because St. Luke tries to point out that the Christian teaching founded by our Savior Jesus Christ is not a dangerous and anti-Roman movement, but on the contrary, Christian teaching is based on sound moral principles and a sacred life that gravitates around the communion and love of the neighbor ${ }^{21}$.

In summary, St. Luke claims that the early Christians are somewhat favored by the Roman political system. Clearly, St. Luke does not face in his days an open hostility to Christianity from the Roman authorities. According to Luke, not all Romans and not all the Jews oppose Christians and at least one Herodian prince, Agrippa II is open and favorable to the Christian doctrine. Moreover, some of the Romans became Christians, and Cornelius is the first pagan converting. The moment of the conversion of the centurion Cornelius gives Saint Luke the opportunity to

20 Constantin PREDA, „Credinţa şi viaţa Bisericii primare. O analiză a Faptelor Apostolilor”..., p. 148.

${ }^{21}$ Alexandru TUDOR, „Viaţa sacramentală a Bisericii în Faptele Apostolilor”, în rev. Studii Teologice, anul XXXII, nr 1-2, 1980, pp 196-198. 
highlight the theological motivation of the free and unconditional entry of the pagans into the church, but at the same time a relationship between Christians and pagans. Taking into account the lucid tendency to formulate the narrative around the principle of symmetry ${ }^{22}$, we find that the author of the Acts of the Book of Apostles emphasizes that Roman officials begin to treat Christians with justice and good will, protect them from the abuses and intrigues of the Jews or other political factions. Roman laws and customs do not prevent Christians from preaching Christ.

The Jewish problems and disputes are of no importance to the Romans, and according to the Lukan theology, there is no political power, including the Roman one, able to oppose God's plan. A particularly important fact is the work of St. Apostle Paul during the Roman captivity recorded in the epilogue of the book The Acts of the Holy Apostles and where it is stated that he had the benefit of custodia militaris (military custody) which entitles him to live under guard in a particular house ${ }^{23}$.

It follows from the above that both the activity of Christians and the principles of their faith do not create problems or difficulties in a rational government system. Only an irrational government or a people guided by religious prejudgements and/or hatred can find a fault of Christianity and teachings preached by him.

In any system based on sound principles, Christians turn out to be good citizens, and this is also the image of Christianity that St. Luke wanted to pass on to his readers and to the successors.

${ }^{22}$ A. W. ZWEIP, The Ascension of the Messiah in Lukan Christology, New York, Brill, 1997, p. 115.

23 IPS Bartolomeu Valeriu ANANIA, Biblia sau Sfânta Scriptură, Ediție Jubiliară a Sfântului Sinod, București, Editura Institutului Biblic și de Misiune al Bisericii Ortodoxe Române, 2001, nota explicativă e, p. 1620. 
Although St. Luke, in the first chapters of the book of the Acts allows us to see the relevance of our Christian faith and of life of the first communities, over the time, the historicalreligious framework has undergone some changes due to the fact that the political, economic and moral situation has changed in the Roman Empire.

These were the relations between Judaism, the political class of the Roman Empire and Christianity, previous to the missionary journeys of St. Paul the Apostle, and unfortunately these relations will become constant and will be found as negative aspects in the missionary journeys of the Apostle of the Gentiles.

However, Romans, being eclectic, will allow and tolerate any kind of faith, as long as it will not prevent people from taking part in the worship system existing in the empire and imposed by the Roman state.

In order to be able to perceive the missionary activity of the one who would become the Apostle of Christ among the gentiles, we will have to give priority to the environment to which he makes reference and in which he will carry out his mission of preaching the Word of God. 